\title{
Linear and Annular Lupus Panniculitis of the Scalp: Case Report with Emphasis on Trichoscopic Findings and Review of the Literature
}

\section{Siriorn Udompanich Kumutnart Chanprapaph Poonkiat Suchonwanit}

Division of Dermatology, Faculty of Medicine, Ramathibodi Hospital, Mahidol University, Bangkok, Thailand

\section{Keywords}

Alopecia · Blaschko's line · Hair loss · Linear lupus · Lupus panniculitis

\begin{abstract}
Linear and annular lupus panniculitis of the scalp (LALPS) is a unique subset of lupus panniculitis, which results in non-scarring alopecia along the Blaschko line of the scalp in an otherwise healthy young patient. Numerous cases have been reported around the world, but data on their trichoscopic findings and correlations with the underlying pathology is sparse. We hereby present a case of 23-year-old male with LALPS and further describe his trichoscopic findings as well as their correlations with histopathological features.

(C) 2019 The Author(s)

Published by S. Karger AG, Basel
\end{abstract}

\section{Introduction}

Lupus panniculitis contributes to $1-3 \%$ of all specific cutaneous lupus erythematosus (LE) cases and presents with indurated erythematous subcutaneous nodule or plaque. It 
typically appears on the face, proximal extremities, and on the trunk [1-3]. Histopathological sections reveal lobular panniculitis with predominant lymphocytic infiltration, accompanied by hyaline fat necrosis [4]. The scalp can be involved in up to $16.7 \%$ of the cases [2]. Lesions on the scalp either share similar characteristics with classic lupus panniculitis, with indurated erythematous plaque resulting in scarring alopecia, or they take a distinct form that is nonscarring and follows the Blaschko lines of the scalp [5]. The latter was first described by Nagai et al. [6] in 2003. Since then, similar cases have been increasingly recognized, confirming its unique presentation and clinical course. The condition was later termed linear lupus panniculitis of the scalp or linear and annular lupus panniculitis of the scalp (LALPS) [5]. Nevertheless, there are limited data on the trichoscopic findings and correlations with the underlying pathology. We hereby present a case of 23-year-old male with LALPS and further describe his trichoscopic findings as well as their correlations with histopathological features.

\section{Case Presentation}

A 23-year-old male presented with localized hair loss on his right parietal scalp. The lesion was asymptomatic and gradually expanded over the course of 5 months. The patient was otherwise well with no known underlying pathology or any history suggesting systemic involvement, such as joint pain and photosensitive rash. On examination, there was a non-scarring alopecia patch, approximately $8 \mathrm{~cm}$ in diameter, with bizarre configuration and faint erythema on the right parietal scalp and without any induration or atrophy (Fig. 1). The hair appeared normal; both hair pull and rolling tests were negative. His complete blood count, blood urea nitrogen, serum creatinine, liver function tests, urinalysis, and veneral disease research laboratory test were all within normal limits, while a speckled-pattern antinuclear antibody was detected with a titer of 1:160.

Trichoscopic examination revealed several hair shaft abnormalities, including broken hair, exclamation mark hair, angulated hair, and short regrowing hair (Fig. 2a). Scalp changes were also evident. The erythema on the interfollicular areas turned out to be prominent blood vessels (Fig. 2b). Some hairs were broken inside the follicles at the scalp level and appeared as black dots. The sparse yellow dots were displayed in variable sizes, with some larger than others (Fig. 2b). On histopathology, focal interface changes with vacuolar alteration and occasional necrosis of basal keratinocytes were detected. The dense perivascular, perifollicular, and interstitial inflammatory cell infiltrates of mainly lymphocytes were found within the dermis, with dense nodular infiltration in the fat lobules of the subcutaneous tissue, along with some hyalinized necrosis of fat cells (Fig. 3a). A close examination at the uppermost level of the horizontal section showed perifollicular infiltration, fibroplasia, as well as dilatation of the follicles and keratin plugging (Fig. 3b).

From his clinical presentation and supporting histopathological findings, we arrived at the diagnosis of LALPS. In accordance with previously reported cases of LALPS, several treatments, including hydroxychloroquine, corticosteroids (systemic, intralesional, or topical), methotrexate, mycophenolate mofetil, cyclophosphamide, dapsone, gold therapy, and topical minoxidil) were found to be effective. The patient was given oral hydroxychloroquine $200 \mathrm{mg}$ once daily and $0.05 \%$ clobetasol propionate solution to apply on the lesion twice daily. Almost 
complete hair regrowth was achieved within 3 months. There has been no recurrence during the follow-up period of 1 year.

\section{Discussion}

LALPS is a distinct type of lupus panniculitis that follows the Blaschko line. Table 1 and Table 2 summarize all case reports that are available in full text. A majority of patients were young East Asian males, but females and Caucasians were also affected. All cases achieved significant improvement or complete hair regrowth after the administration of oral prednisolone or hydroxychloroquine, with very few recurrences. While antinuclear antibodies were positive in almost half of the patients, only 1 fulfilled the criteria for systemic LE (SLE). Chen et al. [7] compared LALPS to classic lupus panniculitis and concluded that LALPS occurs at a younger age, predominantly in East Asian males, has a reversible clinical course, and fewer associations with SLE.

The true pathomechanism of LALPS is largely unknown. The most striking features that discriminate this condition from classic lupus panniculitis are its non-scarring nature and distribution along the Blaschko line. It was speculated that the inflammation is confined to the subcutaneous layer; hence, the stem cells in the hair bulge are well preserved, allowing spontaneous hair regrowth once the inflammation has subsided. Alternatively, the condition may have appeared to be non-scarring because it was treated early. We suspect that if the inflammation persists and expands upward, the hair bulge can be involved, leading to subsequent scarring alopecia. The horizontal section from our patient revealed signs of early fibrosis at the hair follicles, which supports this hypothesis. The Blaschko line predilection is more challenging to explain. Some believe the lesion is caused by genetically programmed cloning of cells along the Blaschko lines from early embryogenesis [8]. A recent review by Luengarun et al. [9] suggested that the disease mostly occurs on the parietal scalp (70\%) and does not always follow the Blaschko line distribution. However, the exact pattern of Blascko's line on the head and neck remains to be established and may vary between individuals.

Our case offers further insight into the trichoscopic features of LALPS and demonstrates some trichoscopic and histopathological correlations. Numerous signs have indicated insult to the hair shaft. Angulated hairs are fracture hairs with a sharp angle along the hair shaft [10]. Complete fracture of the hair above the follicles is seen as broken hair and at the follicular level as black dots, while exclamation mark hair suggests a slow progressive insult at the level of hair formation. All these signs may be explained by the nodular perifollicular infiltration with lymphocytic predominance on histopathology, leading to destruction of the lower part of the hair. The broken hair, black dots, angulated hair, and especially exclamation mark hair, are hallmarks of alopecia areata (AA), in which dense nodular follicular infiltration or "swarm of bees" is also the main histopathological feature [10-12]. Moreover, the keratin plugs, which are follicular hyperkeratosis on histopathology, are consistent with large yellow dots on trichoscopy.

Differential diagnosis of LALPS includes conditions with localized non-scarring alopecia such as AA, trichotillomania, and syphilitic alopecia [5]. Broken hair, black dots, and yellow dots are all features of these disorders [11]; however, certain clues could point towards LALPS. The size of the blood vessels was noted to be larger in cutaneous LE when compared 
to those of AA. The yellow dots also appeared to be larger and darker [13]. Thorough history taking and laboratory investigations may help exclude trichotillomania and syphilitic alopecia, and histopathology can always give a definite diagnosis. Another differential diagnosis is a further subtype of cutaneous LE on the scalp termed "non-scarring patchy alopecia in SLE." It presents with localized non-scarring patches with similar trichoscopic features, especially regarding predominant blood vessels. However, the disorder is restricted to patients with SLE, often in cases with severe exacerbations, unlike LALPS where the risk of SLE is extremely low. The patches resemble AA, do not follow a bizarre distribution, or involve the subcutaneous tissue on histopathology $[5,14,15]$.

In conclusion, we report a case of localized non-scarring alopecia along the suspected Blaschko line and biopsy results consistent with lupus panniculitis. Trichoscopic examination displayed hair shaft abnormalities, including broken hair, exclamation mark hair, angulated hair, and short regrowing hair. Furthermore, scalp changes such as prominent blood vessels and yellow dots were present. While most signs can be found in other conditions with nonscarring alopecia, prominent blood vessels should alert clinicians to the possibility of LALPS. Furthermore, continuing follow-up is recommended due to the possibility of LALPS recurrence and the development of SLE.

\section{Statement of Ethics}

The patient provided written informed consent to perform all necessary investigations, to take clinical photographs, and to use them for research purposes and publication.

\section{Disclosure Statement}

The authors have no conflicts of interest to declare.

\section{Author Contributions}

All named authors meet the International Committee of Medical Journal Editors (ICMJE) criteria for authorship for the manuscript, take responsibility for the integrity of the work as a whole, and gave final approval to the version to be published.

\section{References}

1 Park HS, Choi JW, Kim BK, Cho KH. Lupus erythematosus panniculitis: clinicopathological, immunophenotypic, and molecular studies. Am J Dermatopathol. 2010 Feb;32(1):24-30.

2 Arai S, Katsuoka K. Clinical entity of Lupus erythematosus panniculitis/lupus erythematosus profundus. Autoimmun Rev. 2009 May;8(6):449-52.

3 Peters MS, Su WP. Lupus erythematosus panniculitis. Med Clin North Am. 1989 Sep;73(5):1113-26.

4 Sánchez NP, Peters MS, Winkelmann RK. The histopathology of lupus erythematosus panniculitis. J Am Acad Dermatol. 1981 Dec;5(6):673-80. 
5 Udompanich S, Chanprapaph K, Suchonwanit P. Hair and scalp changes in cutaneous and systemic lupus erythematosus. Am J Clin Dermatol. 2018 Oct;19(5):679-94.

6 Nagai Y, Ishikawa 0, Hattori T, Ogawa T. Linear lupus erythematosus profundus on the scalp following the lines of Blaschko. Eur J Dermatol. 2003 May-Jun;13(3):294-6.

7 Chen YA, Hsu CK, Lee JY, Yang CC. Linear lupus panniculitis of the scalp presenting as alopecia along Blaschko's lines: a distinct variant of lupus panniculitis in East Asians? J Dermatol. 2012 Apr;39(4):385-8.

8 Marzano AV, Tanzi C, Caputo R, Alessi E. Sclerodermic linear lupus panniculitis: report of two cases. Dermatology. 2005;210(4):329-32.

9 Lueangarun S, Subpayasarn U, Tempark T. Distinctive lupus panniculitis of scalp with linear alopecia along Blaschko's lines: a review of the literature. Int J Dermatol. 2019 Feb;58(2):144-50.

10 Khunkhet S, Vachiramon V, Suchonwanit P. Trichoscopic clues for diagnosis of alopecia areata and trichotillomania in Asians. Int J Dermatol. 2017 Feb;56(2):161-5.

11 Miteva M, Tosti A. Hair and scalp dermatoscopy. J Am Acad Dermatol. 2012 Nov;67(5):1040-8.

12 Sperling LC, Sinclair RD, Shabrawi-Caelen LE. Alopecias. In: Bolognia JL, Schaffer A, Cerroni L, editors. Dermatology. Volume 1. Amsterdam: Elsevier Saunders; 2017. pp. 1162-85.

13 Rakowska A, Slowinska M, Kowalska-Oledzka E, Warszawik O, Czuwara J, Olszewska M, et al. Trichoscopy of cicatricial alopecia. J Drugs Dermatol. 2012 Jun;11(6):753-8.

14 Ye Y, Zhao Y, Gong Y, Zhang X, Caulloo S, Zhang B, et al. Non-scarring patchy alopecia in patients with systemic lupus erythematosus differs from that of alopecia areata. Lupus. 2013 Dec;22(14):1439-45.

15 Suchonwanit P, Udompanich S, Thadanipon K, Chanprapaph K. Trichoscopic signs in systemic lupus erythematosus: a comparative study with 109 patients and 305 healthy controls. J Eur Acad Dermatol Venereol. 2019 Apr;33(4):774-80.

$16 \mathrm{Wu} \mathrm{CP}, \mathrm{Tsai} \mathrm{TF}$. Linear lupus erythematosus profundus on the scalp following the lines of Blaschko in an adult. Zhonghua Pifuke Yixue Zazhi. 2004 Jun;22:166-72.

17 Bacanli A, Uzun S, Ciftcioglu MA, Alpsoy E. A case of lupus erythematosus profundus with unusual manifestations. Lupus. 2005;14(5):403-5.

18 Rhee CH, Kim SM, Kim MH, Cinn YW, Ihm CW. Two cases of linear alopecia on the occipital scalp. Ann Dermatol. 2009 May;21(2):159-63.

19 Tsuzaka S, Ishiguro N, Akashi R, Kawashima M. A case of lupus erythematosus profundus with multiple arcshaped erythematous plaques on the scalp and a review of the literature. Lupus. 2012 May;21(6):662-5.

20 Pandhi D, Verma P, Singal A, Sharma S, Tondon A. Atypical lupus erythematosus panniculitis progressing to antinuclear antibody-negative systemic lupus erythematosus. J Cutan Med Surg. 2012 Sep-0ct;16(5):361-4.

21 Chiesa-Fuxench ZC, Kim EJ, Schaffer A, Fett N. Linear lupus panniculitis of the scalp presenting as alopecia along Blaschko's lines: a variant of lupus panniculitis not unique to East Asians. J Dermatol. 2013 Mar;40(3):231-2.

22 Mitxelena J, Martínez-Peñuela A, Cordoba A, Yanguas I. Linear and annular lupus panniculitis of the scalp. Actas Dermosifiliogr. 2013 Dec;104(10):936-9.

23 Kiritsi D, Diaz-Cascajo C, Hoffmann R, Happle R, Jakob T, Kern JS. A band-like balding disorder. Lancet. 2014 Feb;383(9917):e14.

24 Kshetrimayum S, Thokchom N, Hmar V. Linear non scarring alopecia of the scalp: a rare manifestation of lupus panniculitis. Indian J Dermatol. 2016 Sep-Oct;61(5):581.

25 Lueangarun S, Subpayasarn U, Chakavittumrong P, Tempark T, Suthiwartnarueput W. Lupus panniculitis of the scalp presenting with linear alopecia along the lines of Blaschko. Clin Exp Dermatol. 2017 Aug;42(6):705-7.

26 Park SK, Kwak HB, Yun SK, Kim HU, Park J. Two annular alopecic lesions on the scalp in a young asian man: a quiz. Acta Derm Venereol. 2017 Mar;97(3):418-9. 


\section{Case Reports in Dermatology}

Case Rep Dermatol 2019;11:157-165 www.karger.com/cde

Udompanich et al: Linear and Annular Lupus Panniculitis of the Scalp: Case Report with Emphasis on Trichoscopic Findings and Review of the Literature

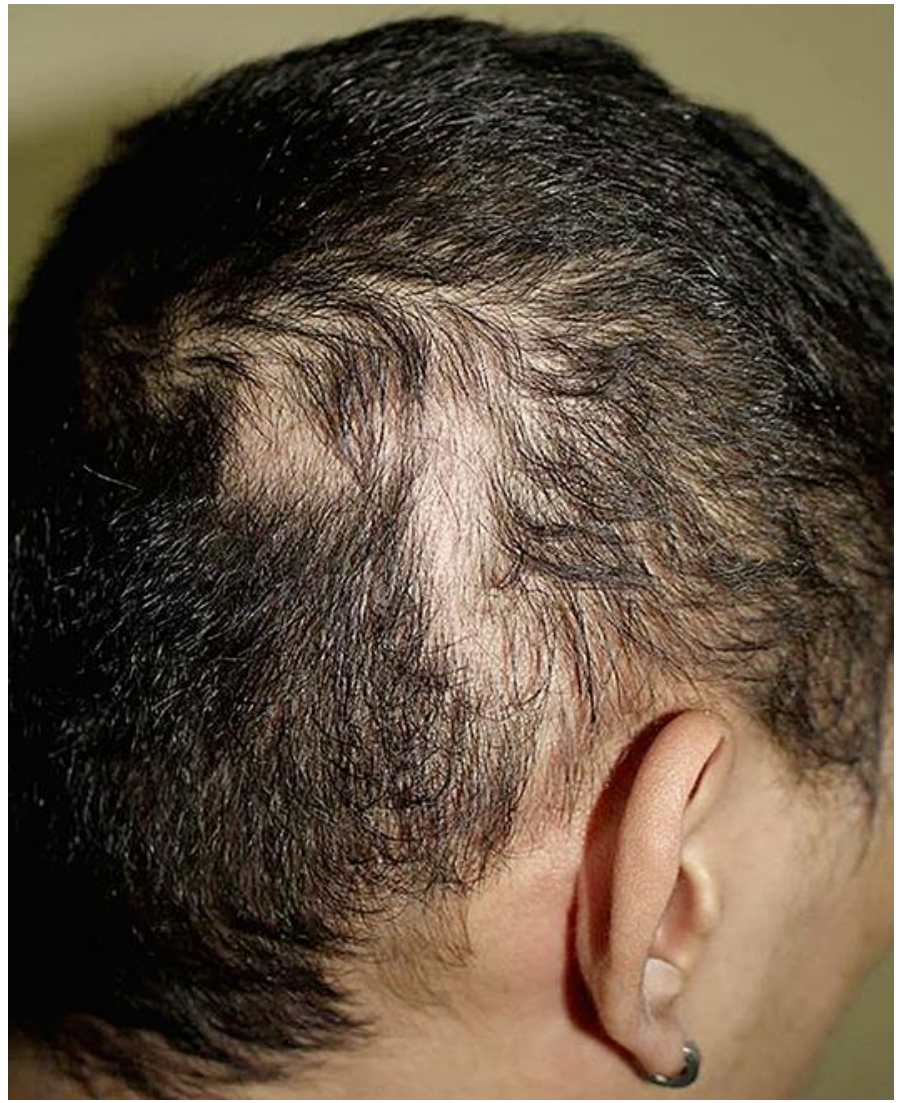

Fig. 1. Localized non-scarring alopecia with bizarre distribution on the right parietal scalp. 


\section{Case Reports in Dermatology}
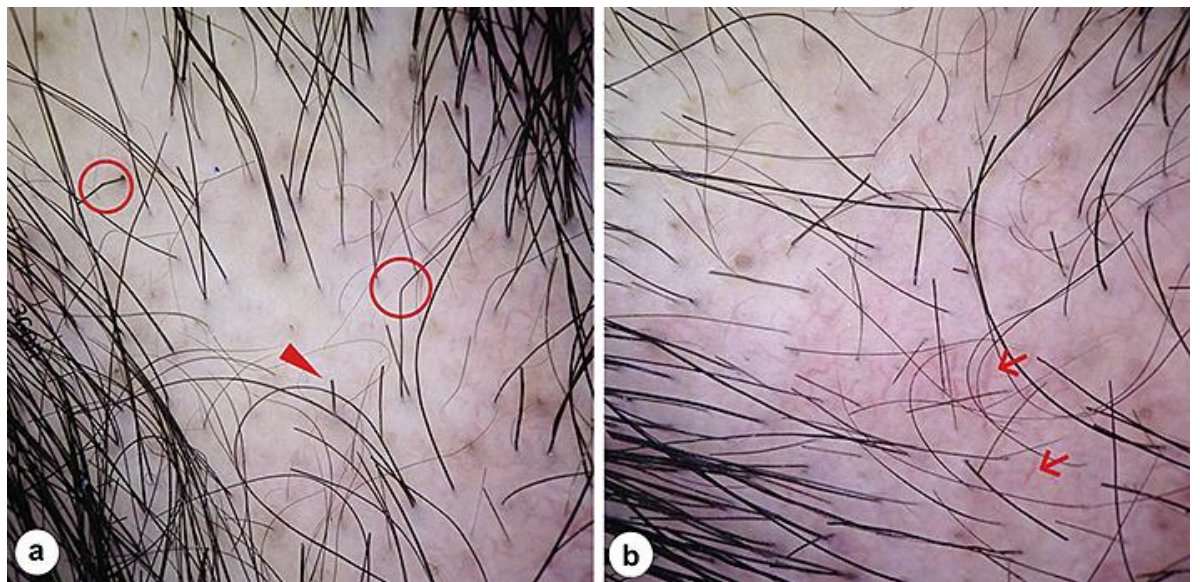

Fig. 2. Trichoscopic features of LALPS (magnification $\times 20$ ). a Hair shaft abnormalities: broken hair, exclamation mark hair (arrowhead), angulated hair (circles), and short regrowing hair. b Scalp changes: prominent blood vessels (arrows) and yellow dots of variable sizes.
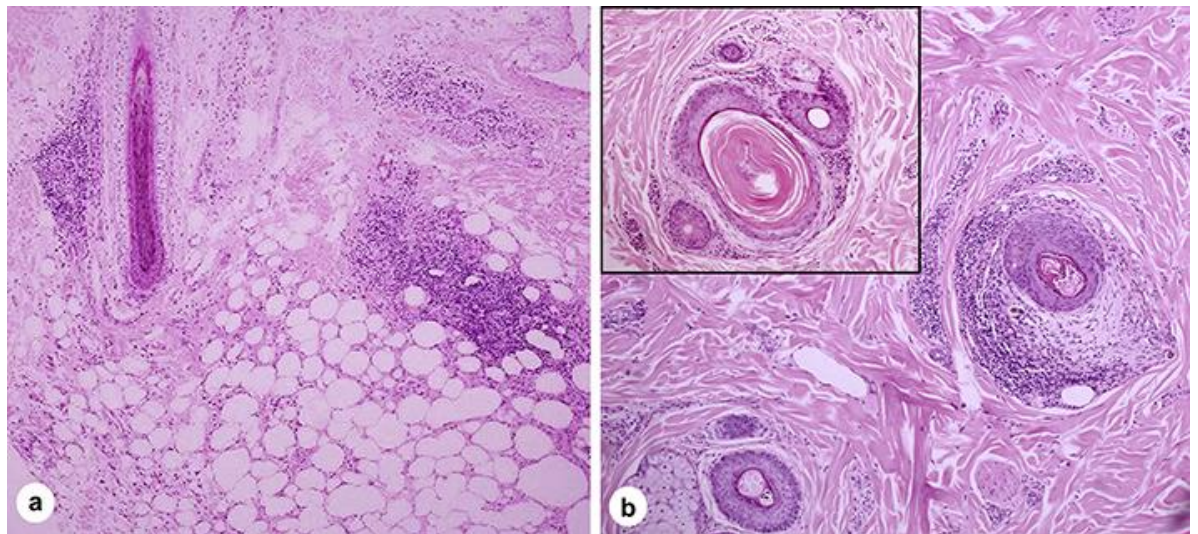

Fig. 3. Histopathologic features of LALPS. a Dense perivascular, perifollicular, and interstitial lymphocytic infiltration in the dermis and lobular panniculitis in the subcutaneous tissue (hematoxylin-eosin. $\times 40$ ), with some hyalinized necrosis of fat cells (hematoxylin-eosin. $\times 100$ ). $\mathbf{b}$ Close examination at the uppermost level of the horizontal section (hematoxylin-eosin. $\times 100$ ) showing perifollicular infiltration, fibroplasia, dilatation of the follicles, and keratin plugging (inset). 


\section{Case Reports in Dermatology}

\begin{tabular}{l|l}
\hline DOI: 10.1159/000500848 & $\begin{array}{l}\text { (c) } 2019 \text { The Author(s). Published by S. Karger AG, Basel } \\
\text { www.karger.com/cde }\end{array}$
\end{tabular}

Udompanich et al.: Linear and Annular Lupus Panniculitis of the Scalp: Case Report with

Emphasis on Trichoscopic Findings and Review of the Literature

Table 1. Available case reports of linear and annular lupus panniculitis of the scalp

\begin{tabular}{|c|c|c|c|c|c|c|c|c|}
\hline $\begin{array}{l}\text { First } \\
\text { author, } \\
\text { year [ref.] }\end{array}$ & $\begin{array}{l}\text { Age of onset, } \\
\text { years/ } \\
\text { sex }\end{array}$ & $\begin{array}{l}\text { Race/ } \\
\text { ethnicity }\end{array}$ & $\begin{array}{l}\text { Clinical } \\
\text { presentation }\end{array}$ & $\begin{array}{l}\text { Duration } \\
\text { of disease }\end{array}$ & Histology & $\begin{array}{l}\text { Direct } \\
\text { immuno- } \\
\text { fluorescence }\end{array}$ & $\begin{array}{l}\text { Evidence of } \\
\text { systemic } \\
\text { involvement }\end{array}$ & $\begin{array}{l}\text { Treatment and } \\
\text { outcome }\end{array}$ \\
\hline $\begin{array}{l}\text { Nagai, } \\
2003[6]\end{array}$ & $10 /$ female & Japanese & $\begin{array}{l}\text { Linear and arc-shaped } \\
\text { alopecia on right and left } \\
\text { temporal scalp with } \\
\text { band-like erythema }\end{array}$ & 2 months & $\begin{array}{l}\text { Normal epidermis } \\
\text { Perivascular and periadnexal } \\
\text { lymphocytic infiltration } \\
\text { Fat degeneration } \\
\text { Abundant mucin }\end{array}$ & n.a. & $\begin{array}{l}\text { ANA positive } \\
1: 320 \\
\text { homogenous } \\
\text { and speckled } \\
\text { pattern }\end{array}$ & $\begin{array}{l}\text { Topical steroid } \\
\text { No improvement }\end{array}$ \\
\hline $\begin{array}{l}\mathrm{Wu}, \\
2004[16]\end{array}$ & $21 /$ female & Taiwanese & $\begin{array}{l}\text { Spiral-shaped non-scarring } \\
\text { alopecia on the frontal and } \\
\text { parietal areas along the } \\
\text { Blaschko line }\end{array}$ & 1 year & $\begin{array}{l}\text { Normal epidermis } \\
\text { Perieccrine aggregation of } \\
\text { plasma cells and lymphocytes } \\
\text { in the dermosubcutaneous } \\
\text { junction } \\
\text { Fat degeneration, abundant } \\
\text { deposition of mucoid } \\
\text { material through the } \\
\text { dermis and the fat tissue }\end{array}$ & n.a. & $\begin{array}{l}\text { Blood tests all } \\
\text { normal }\end{array}$ & $\begin{array}{l}\text { HCQ } \\
\text { Complete } \\
\text { resolution in one } \\
\text { year }\end{array}$ \\
\hline $\begin{array}{l}\text { Bacanli, } \\
2005[17]\end{array}$ & $16 /$ female & n.a. & $\begin{array}{l}\text { Annular erythematous plaque } \\
\text { right side of scalp, scarring } \\
\text { alopecia observed on the inner } \\
\text { side of the plaque }\end{array}$ & 2 years & $\begin{array}{l}\text { Follicular hyalinization and } \\
\text { perifollicular lymphocyte } \\
\text { infiltration } \\
\text { Lymphocytic panniculitis, } \\
\text { hyaline degeneration of fat, } \\
\text { hyaline papillary bodies, } \\
\text { lymphocytic nodule }\end{array}$ & $\begin{array}{l}\text { Positive } \mathrm{C} 3 \text { and } \\
\text { IgM in follicular } \\
\text { epithelium }\end{array}$ & $\begin{array}{l}\text { ANA positive } \\
1: 320 \\
\text { homogenous } \\
\text { and nucleolar } \\
\text { pattern }\end{array}$ & $\begin{array}{l}\text { HCQ } \\
\text { Significant } \\
\text { improvement of } \\
\text { the lesion }\end{array}$ \\
\hline \multirow[t]{2}{*}{$\begin{array}{l}\text { Rhee, } \\
2009 \text { [18] }\end{array}$} & $14 /$ male & Korean & $\begin{array}{l}\text { Linear non-scarring alopecia } \\
\text { patch on occipital scalp }\end{array}$ & 9 months & $\begin{array}{l}\text { Epidermis: hyperkeratosis, } \\
\text { follicular plugging } \\
\text { Dermis: perifollicular } \\
\text { lymphoid infiltration, } \\
\text { increased catagen hair } \\
\text { Subcutaneous tissue: dense } \\
\text { mucin deposition, lymphoid } \\
\text { cell infiltration }\end{array}$ & $\begin{array}{l}\text { Negative for } \\
\text { IgM, IgG, IgA, C3 } \\
\text { and fibrinogen }\end{array}$ & n.a. & $\begin{array}{l}\text { HCQ and } \\
\text { prednisolone } \\
\text { Hair regrowth } \\
\text { from 8th week, } \\
\text { complete } \\
\text { remission }\end{array}$ \\
\hline & $32 / \mathrm{male}$ & Korean & $\begin{array}{l}\text { Linear non-scarring alopecia } \\
\text { patch on occipital scalp }\end{array}$ & 2 years & $\begin{array}{l}\text { Similar to case one but less } \\
\text { perifollicular infiltration }\end{array}$ & $\begin{array}{l}\text { Negative for } \\
\text { IgM, IgG, IgA, C3 } \\
\text { and fibrinogen }\end{array}$ & n.a. & $\begin{array}{l}\text { Dapsone } \\
\text { Hair regrowth } \\
\text { )no } \mathrm{F} / \mathrm{U}(\end{array}$ \\
\hline $\begin{array}{l}\text { Chen, } \\
2012 \text { [7] }\end{array}$ & $32 /$ male & Taiwanese & $\begin{array}{l}\text { Linear and wavy non-scarring } \\
\text { alopecia on occipital scalp } \\
\text { along Blaschko's line, faint } \\
\text { interfollicular erythema and } \\
\text { follicular plugging }\end{array}$ & 6 months & $\begin{array}{l}\text { Normal epidermis } \\
\text { Dermis: peribulbar } \\
\text { infiltration of lymphocytes } \\
\text { and plasma cells } \\
\text { Subcutaneous tissue: mucin } \\
\text { deposition, lymphoplasmo- } \\
\text { cytic infiltration }\end{array}$ & $\begin{array}{l}\text { Negative for } \\
\text { IgG, IgA, IgM } \\
\text { and C3 }\end{array}$ & $\begin{array}{l}\text { Blood tests } \\
\text { all normal }\end{array}$ & $\begin{array}{l}\text { HCQ, IL steroid } \\
\text { Complete hair } \\
\text { regrowth but } \\
\text { recurred after } 9 \\
\text { months }\end{array}$ \\
\hline $\begin{array}{l}\text { Tsuzaka, } \\
2012[19]\end{array}$ & $26 /$ male & Japanese & $\begin{array}{l}\text { Multiple arc-shaped } \\
\text { erythematous plaques with } \\
\text { non-scarring alopecia }\end{array}$ & 2 years & $\begin{array}{l}\text { Dermis: perivascular } \\
\text { lymphocytic infiltration } \\
\text { Subcutaneous tissue: lobular } \\
\text { and septal panniculitis, mucin } \\
\text { deposition }\end{array}$ & $\begin{array}{l}\text { Granular } \\
\text { deposits of IgG } \\
\text { along DEJ }\end{array}$ & $\begin{array}{l}\text { ANA positive } \\
1: 1,280 \\
\text { speckled } \\
\text { pattern } \\
\text { Anti-Ro } \\
\text { positive }\end{array}$ & $\begin{array}{l}\text { Prednisolone } \\
\text { Complete hair } \\
\text { regrowth }\end{array}$ \\
\hline
\end{tabular}

n.a., data not available; ANA, antinuclear antibodies; HCQ, hydroxychloroquine; IL, intralesional; DEJ, dermo-epidermal junction; SLE, systemic lupus erythematosus. 


\section{Case Reports in Dermatology}

Udompanich et al.: Linear and Annular Lupus Panniculitis of the Scalp: Case Report with

Emphasis on Trichoscopic Findings and Review of the Literature

Table 2. Available case reports of linear and annular lupus panniculitis of the scalp (continued)

\begin{tabular}{|c|c|c|c|c|c|c|c|c|}
\hline $\begin{array}{l}\text { First } \\
\text { author, } \\
\text { year [ref.] }\end{array}$ & $\begin{array}{l}\text { Age of onset, } \\
\text { years/ } \\
\text { sex }\end{array}$ & $\begin{array}{l}\text { Race/ } \\
\text { ethnicity }\end{array}$ & $\begin{array}{l}\text { Clinical } \\
\text { presentation }\end{array}$ & $\begin{array}{l}\text { Duration } \\
\text { of disease }\end{array}$ & Histology & $\begin{array}{l}\text { Direct } \\
\text { immuno- } \\
\text { fluorescence }\end{array}$ & $\begin{array}{l}\text { Evidence of } \\
\text { systemic } \\
\text { involvement }\end{array}$ & $\begin{array}{l}\text { Treatment and } \\
\text { outcome }\end{array}$ \\
\hline $\begin{array}{l}\text { Pandhi, } \\
2012[20]\end{array}$ & $25 /$ male & Indian & $\begin{array}{l}\text { Annular non- } \\
\text { scarring alopecic } \\
\text { patch on frontal } \\
\text { scalp }\end{array}$ & n.a. & $\begin{array}{l}\text { Hyperkeratosis, follicular } \\
\text { plugging, basal vacuolization } \\
\text { Superficial and deep perivascu- } \\
\text { lar and perifollicular lympho- } \\
\text { cytic infiltration lobular } \\
\text { panniculitis }\end{array}$ & $\begin{array}{l}\text { Granular } \\
\text { deposition of } \\
\text { IgG, IgM, IgA } \\
\text { and C3 along } \\
\text { DEJ }\end{array}$ & $\begin{array}{l}\text { Developed } \\
\text { SLE } 2 \text { years } \\
\text { later }\end{array}$ & $\begin{array}{l}\text { Prednisolone, HCQ } \\
\text { Improved but } \\
\text { with partial } \\
\text { scarring after } \\
8 \text { weeks of } \\
\text { therapy }\end{array}$ \\
\hline $\begin{array}{l}\text { Chiesa- } \\
\text { Fuxench, } \\
2013[21]\end{array}$ & $26 /$ male & Caucasian & $\begin{array}{l}\text { Arc-shaped linear } \\
\text { patches of non- } \\
\text { scarring alopecia over } \\
\text { right parietal and } \\
\text { occipital scalp along } \\
\text { the line of Blaschko }\end{array}$ & n.a. & $\begin{array}{l}\text { Superficial and deep lympho- } \\
\text { cytic infiltration with mucin } \\
\text { deposition within the dermis } \\
\text { and extension into the } \\
\text { subcutaneous fat }\end{array}$ & n.a. & $\begin{array}{l}\text { Blood tests } \\
\text { all normal }\end{array}$ & $\begin{array}{l}\text { Prednisolone, } \\
\text { HCQ IL steroid } \\
\text { Complete hair } \\
\text { regrowth }\end{array}$ \\
\hline $\begin{array}{l}\text { Mitxelena, } \\
2013 \text { [22] }\end{array}$ & $34 /$ male & Caucasian & $\begin{array}{l}\text { Erythematous } \\
\text { edematous annular } \\
\text { and linear plaques } \\
\text { of non-scarring } \\
\text { alopecia on vertex } \\
\text { and parietal scalp }\end{array}$ & 1 year & $\begin{array}{l}\text { Dense lymphocytic infiltrate } \\
\text { affecting the deep dermis and } \\
\text { adipose tissue, fat necrosis and } \\
\text { vacuolar damage of the basal } \\
\text { layer of the epidermis }\end{array}$ & $\begin{array}{l}\text { Granular } \\
\text { deposits of } \\
\text { IgM along } \\
\text { DEJ }\end{array}$ & $\begin{array}{l}\text { ANA 1:320 } \\
\text { Anti-Ro } \\
\text { positive }\end{array}$ & $\begin{array}{l}\text { HCQ prednisolone } \\
\text { Resolved but } \\
\text { recurred after } \\
1 \text { year }\end{array}$ \\
\hline $\begin{array}{l}\text { Kiritsi, } \\
2014[23]\end{array}$ & $34 /$ male & Caucasian & $\begin{array}{l}\text { Linear non-scarring } \\
\text { alopecia along } \\
\text { Blaschko's line }\end{array}$ & 1 year & $\begin{array}{l}\text { Normal epidermis } \\
\text { Accumulation of mucin in } \\
\text { the dermis lymphocytic } \\
\text { panniculitis }\end{array}$ & n.a. & ANA 1:200 & $\begin{array}{l}\text { HCQ } \\
\text { Complete hair } \\
\text { regrowth in } \\
12 \text { weeks }\end{array}$ \\
\hline $\begin{array}{l}\text { Kshetrimayum, } \\
2016[24]\end{array}$ & $17 /$ male & Indian & $\begin{array}{l}\text { Two linear non- } \\
\text { scarring alopecic } \\
\text { patches with mild } \\
\text { erythema and } \\
\text { tenderness on } \\
\text { temporal and frontal } \\
\text { scalp }\end{array}$ & 7 years & $\begin{array}{l}\text { Dermis: moderate perivascular } \\
\text { lymphocytic infiltration } \\
\text { Subcutaneous tissue: fat } \\
\text { necrosis, myxoid degeneration } \\
\text { and hyaline deposits in the } \\
\text { interlobular septa }\end{array}$ & n.a. & $\begin{array}{l}\text { Blood tests } \\
\text { all normal }\end{array}$ & $\begin{array}{l}\text { Prednisolone, HCQ } \\
\text { Complete hair } \\
\text { regrowth }\end{array}$ \\
\hline $\begin{array}{l}\text { Luengarun, } \\
2017 \text { [25] }\end{array}$ & 28/male & Burmese & $\begin{array}{l}\text { Linear non-scarring } \\
\text { alopecia on vertex } \\
\text { and parietal areas } \\
\text { Hair pull negative }\end{array}$ & 1 year & $\begin{array}{l}\text { Epidermis and dermis: dense } \\
\text { perifollicular lymphoid infiltra- } \\
\text { tion, vacuolar interface along } \\
\text { infundibular epithelium, } \\
\text { epidermal atrophy, follicular } \\
\text { plugging } \\
\text { Subcutaneous tissue: fat } \\
\text { necrosis, mucin infiltration }\end{array}$ & n.a. & $\begin{array}{l}\text { ANA 1:320 } \\
\text { speckled } \\
\text { pattern }\end{array}$ & $\begin{array}{l}\text { Prednisolone, } \\
\text { HCQ IL steroid, } \\
\text { topical 5\% } \\
\text { minoxidil lotion } \\
\text { Remarkable } \\
\text { improvement }\end{array}$ \\
\hline $\begin{array}{l}\text { Park, } \\
2017 \text { [26] }\end{array}$ & $18 /$ male & Korean & $\begin{array}{l}\text { Arc-shaped, non- } \\
\text { scarring alopecic } \\
\text { patches on right } \\
\text { frontal-parietal and } \\
\text { left temporoparietal } \\
\text { scalp }\end{array}$ & 1 year & $\begin{array}{l}\text { Dense lymphocytic infiltrates } \\
\text { mainly in the peribulbar and } \\
\text { interfollicular areas in lower } \\
\text { dermis and subcutaneous } \\
\text { tissue }\end{array}$ & n.a. & $\begin{array}{l}\text { ANA 1:20 } \\
\text { speckled } \\
\text { pattern }\end{array}$ & $\begin{array}{l}\text { HCQ } \\
\text { Improved in } \\
12 \text { weeks }\end{array}$ \\
\hline Present case & 23/male & Thai & $\begin{array}{l}\text { Non-scarring } \\
\text { alopecic patch with } \\
\text { bizarre configuration } \\
\text { on the right parietal } \\
\text { scalp }\end{array}$ & 5 months & $\begin{array}{l}\text { Epidermis: focal interface } \\
\text { changes with vacuolar altera- } \\
\text { tion and occasional necrosis } \\
\text { of basal keratinocytes } \\
\text { Dermis and subcutaneous } \\
\text { tissue: dense perivascular, } \\
\text { perifollicular, interstitial and } \\
\text { subcutaneous tissue with some } \\
\text { hyalinized necrosis of fat cells }\end{array}$ & n.a. & $\begin{array}{l}\text { ANA 1:160 } \\
\text { speckled } \\
\text { pattern }\end{array}$ & $\begin{array}{l}\text { HCQ topical } \\
\text { steroid } \\
\text { Complete hair } \\
\text { regrowth in } 3 \\
\text { months }\end{array}$ \\
\hline
\end{tabular}

n.a., data not available; ANA, antinuclear antibodies; HCQ, hydroxychloroquine; IL, intralesional; DEJ, dermo-epidermal junction; SLE, systemic lupus erythematosus. 